\title{
Helsesykepleiere er nærmest til å følge opp søsken som pårørende
}

Søsken til barn med en fysisk eller psykisk funksjonsnedsettelse gjør hva de kan for å skjule vansker og normalisere utfordringer av hensyn til familien. Da er det ikke så enkelt å heve stemmen og si ifra.

\section{Torun Marie Vatne}

Psykologspesialist

Fagavdelingen, Frambu kompetansesenter for sjeldne diagnoser

\section{Ann-Helen Kongshaug Rønning}

Psykolog

Alderspsykiatrisk avdeling, Akershus universitetssykehus

\section{Ragnhild Bang-Nes}

Seniorforsker

Psykisk helse og selvmord, Norsk folkehelseinstitutt

Barn

Kommunehelsetjeneste

Pårørende

\section{Hovedbudskap}


Rundt 336 ooo barn i Norge har en kronisk sykdom eller funksjonsnedsettelse, og mange av disse barna har søsken. Søsken som pårørende har større risiko for å utvikle psykiske helseplager. En endring i lovverket i 2018 innebærer at helsesykepleiere nå har en plikt til å avklare pårørende søskens behov for informasjon og oppfølging. Det kan likevel se ut til at mye gjenstår i arbeidet med å følge opp loven.

Det er er lovpålagt at søsken som pårørende skal ivaretas. I januar 2018 trådte en lovendring i kraft som innebærer at helsesykepleiere har plikt til å identifisere og kartlegge behov for informasjon og støtte hos pårørende søsken (1).

Frambu kompetansesenter for sjeldne diagnoser og Folkehelseinstituttet har kartlagt hva 194 helsesykepleiere fra 153 kommuner tenker om oppfølgingen av søsken som pårørende og bedt dem evaluere et forebyggende tiltak rettet mot denne risikogruppen.

\section{Søsken er ofte tause om sine opplevelser}

Søsken som pårørende er en gruppe med utfordringer i hverdagen. I samtaler under kursopphold på Frambu beskriver søsken utfordringene de opplever:

«Jeg har ikke med meg noen hjem, det blir bare så mange spørsmål om hvorfor han er så rar.»

«Jeg vil ikke være alene hjemme, for søsteren min slår meg og truer meg når mamma ikke er der.»

«Hver gang jeg hører en ambulanse, tror jeg det har skjedd noe med broren min.» «Mamma og pappa er så slitne, det er derfor de er så sinna på meg.»

Vi kunne ha fortsatt i det uendelige med slike sitater fra pårørende søsken opplevelsene er like mange som det er barn. Søsken til barn med funksjonsnedsettelser eller kronisk sykdom, uavhengig av om diagnosen er kognitiv, psykisk eller fysisk, møter en rekke utfordringer i hverdagen og har ofte sterke følelsesmessige opplevelser.

Utad oppfattes de gjerne som de kloke, sterke og empatiske barna med stor forståelse for annerledeshet. De er ofte tause om sine opplevelser, de «klarer seg selv», men har behov for at omgivelsene ser hva de står i, for å få støtten de trenger (2). 


\section{Pårørende søsken bør registreres}

Helsesykepleiere er nok de fagpersonene som oppleves som mest tilgjengelige for de fleste barn og unge. «Kan du ikke gå til helsesøster da, det gjør jeg», tipset en ung jente en annen om i en samtalegruppe for søsken. Skolehelsetjenesten er ofte den første instansen barn og unge i Norge søker når de opplever at livet er vanskelig og de trenger helsefaglig støtte (3).

Ikke alle søsken melder sitt behov. «Jeg er på en måte den som skal få vekta til å gå i balanse i familien. Hvis broren min har problemer, så skal ikke jeg ha det», sa en ung jente og beskrev hvordan hun la lokk på vanskene sine for å fylle en rolle.

\section{«Vi kan ikke forvente at disse barna skal 'stå frem' med sin families annerledeshet og søke hjelp.»}

Når du hele livet har jobbet for å skjule vansker og normalisere utfordrende opplevelser av hensyn til familien, er det å heve stemmen og si ifra ikke nødvendigvis så enkelt. Vi kan ikke forvente at disse barna skal «stå frem» med sin families annerledeshet og søke hjelp.

Helsesykepleiere kjenner vanligvis til barnet med funksjonsnedsettelse. En systematisk registrering av søsknene deres er etter vår oppfatning den beste løsningen. Det ser dessverre ut til at dette sjelden skjer i kommunene.

\section{Det er tilfeldig hvordan søsken blir fanget opp}

At helsesykepleiere er en faggruppe som raskt er på ballen og ser seg som aktuelle i arbeidet med pårørende søsken, kom tydelig frem da vi kartla ivaretakelse av søsken som pårørende i norske kommuner.

I 2019 sendte vi ut en forespørsel til helsesykepleiere, kommunepsykologer og kommuneoverleger gjennom e-postmottakene i alle Norges 422 kommuner (per høsten 2019). Vi fikk raskt svar fra helsesykepleierne, men måtte både purre på, og finne andre rekrutteringsformer for, kommunepsykologer og kommuneoverleger.

Majoriteten (61 prosent) av helsesykepleierne i vår unders $\varnothing$ kelse rapporterer om at det er tilfeldig hvordan pårørende søsken blir fanget opp i deres kommune. En fjerdedel melder om systematisk registrering av disse barna i møte med barnet med funksjonsnedsettelse. En svært liten andel oppgir at søsken blir fanget opp systematisk gjennom henvendelse fra spesialisthelsetjenesten. 


\section{Systemet må være på tilbudssiden}

Helsesykepleiere kan tilby tjenester, men får de kontakt med pårørende som er søsken? Mange av deltakerne i vår studie (94 prosent) oppgir at helsestasjonen eller skolehelsetjenesten har et tilbud til pårørende søsken. Likevel tviler vi på at alle som trenger dette tilbudet, nås.

Kun 14 prosent i vår studie oppgir at det rutinemessig gis tilbud om slike tjenester. Majoriteten av helsesykepleierne i unders $\varnothing$ kelsen oppga nemlig at samtaler, enten med søsken selv (94 prosent) eller med foreldre (86 prosent), gis når foreldrene selv etterspør det. Dette innebærer at foreldre må ha overskudd både til å se behovet, til å finne ut hvor et tilbud gis, og til å ta kontakt med dette stedet.

\section{«Pårørende søsken må få vite hva helsesykepleieren kan tilby dem.»}

Vi mener at dette er for mye å forlange. Foreldre til barn med funksjonsnedsettelser har en større omsorgsbyrde i hjemmet, og mange forteller om en stressende og krevende hverdag (4). Barn med utslitte foreldre trenger et system som er på tilbudssiden, og som jobber aktivt med å møte de lovpålagte kravene om å støtte søsken som pårørende.

Forandringsfabrikken, et kunnskapssenter som arbeider for å forbedre hjelpesystemene for barn, ledet nylig et prosjekt med mål om å avdekke hva som skal til for at barn skal ta kontakt med helsesykepleier. Her svarte barna blant annet at de trenger beskjed om hva helsesykepleieren kan tilby (5). Vi sier det samme: Pårørende søsken må få vite hva helsesykepleieren kan tilby dem.

\section{Gruppesamtaler forebygger helseplager}

Er helsesykepleiernes tilbud til søsken kunnskapsbasert? Da støtte til pårørende søsken ble lovpålagt i 2018, fulgte det ikke med økte midler til kommunene. Når ressursene er begrenset, gjelder det å arbeide målrettet og kunnskapsbasert.

Tidligere studier konkluderer med at kommunehelsetjenesten jobber for lite kunnskapsbasert (6). I tråd med dette ser vi et stort forbedringspotensial i helsesykepleiernes arbeid med søsken.

\section{«Hvorfor ikke jobbe både kunnskapsbasert og kostnadseffektivt også i arbeidet med pårørende søsken?»}


Forskning viser at gruppesamtaler er en god metode for å forebygge psykiske helseplager i denne gruppen (7). Gjennom gruppesamtaler kan man samle flere barn på en gang og slik bruke mindre ressurser. Barna kan nyte godt av følelsesmessig støtte fra andre barn i en tilsvarende situasjon, løse problemer i fellesskap, knytte bånd og lære av hverandre i regi av en kompetent og nær voksen.

Til tross for dette rapporterer få (7 prosent) av helsesykepleierne i vår studie at søsken som pårørende får tilbud om gruppesamtaler i deres kommune. Mange helsesykepleiere har allerede erfaring med og kompetanse i å lede barnegrupper for barn i risiko, som for eksempel PIS-grupper for barn med skilte foreldre og SMILgrupper for barn av psykisk syke (se faktaboks). Så hvorfor ikke jobbe både kunnskapsbasert og kostnadseffektivt også i arbeidet med pårørende søsken?

\section{PIS og SMIL}

PIS står for «plan for implementering av samtalegrupper» for skilsmissebarn i skolen. Gruppene arrangeres i skole og barnehage, helt opp til videregående. Målet med gruppene er at barn og unge som strever med at foreldrene har gått fra hverandre, skal få en lettere hverdag og utvikle en psykologisk beredskap for utfordringer senere i livet. Mer informasjon finnes på forebygging.no.

SMIL står for «styrket mestring i livet». Det er utviklet som et lærings- og mestringstilbud for barn og unge som har foreldre med psykisk sykdom eller rusproblemer. Tilbudet beskrives nå også som et tilbud til søsken. Gruppenes mål er læring og styrket mestringsopplevelse. Mer informasjon finnes på mestring.no.

\section{SIBS er en kunnskapsbasert intervensjon}

En forskergruppe fra Frambu kompetansesenter for sjeldne diagnoser og Psykologisk institutt ved Universitetet i Oslo har siden 2012 jobbet målrettet med å utvikle og evaluere metoder for å støtte søsken.

SIBS (basert på det engelske navnet for søsken, siblings) er et resultat av dette arbeidet og er en intervensjon som har som mål å styrke kommunikasjonen mellom foreldre og søsken. Slik ønsker vi å sikre at barna får mer av den informasjonen og emosjonelle støtten de trenger i hverdagen. 
Intervensjonen går over kun fem $\varnothing \mathrm{kter}$, men inneholder både støttegruppe $\varnothing$ kter for barn, psykoedukasjonsgruppe $\varnothing$ kter for foreldre og felles $\varnothing$ kter hvor foreldre og barn $\varnothing$ ver på å snakke sammen under veiledning (8). I en studie gjennomført i 2014-2017 rapporterte 99 deltakere om signifikant bedring i kommunikasjonen mellom foreldre og barn, signifikant $\varnothing$ kning i søskens kunnskap om funksjonsnedsettelsen og signifikant reduksjon av psykiske helseplager hos søsken (9).

\section{Søsken får støtte hverandre som likesinnede}

At en intervensjon fungerer innen rammen av et forskningsprosjekt, er bra, men det aller viktigste er at den fungerer ute $i$ «den virkelige verden» og kan tilpasses ved behov. I arbeidet med å implementere SIBS i Norges kommuner er derfor helsesykepleiernes tanker veldig viktige.

Deltakerne i vår studie fikk se en informasjonsfilm om SIBS (se like under), og på bakgrunn av denne filmen vurderte de kvaliteten på intervensjonen som høy (7,8 i gjennomsnitt på en skala fra 1 til 10).

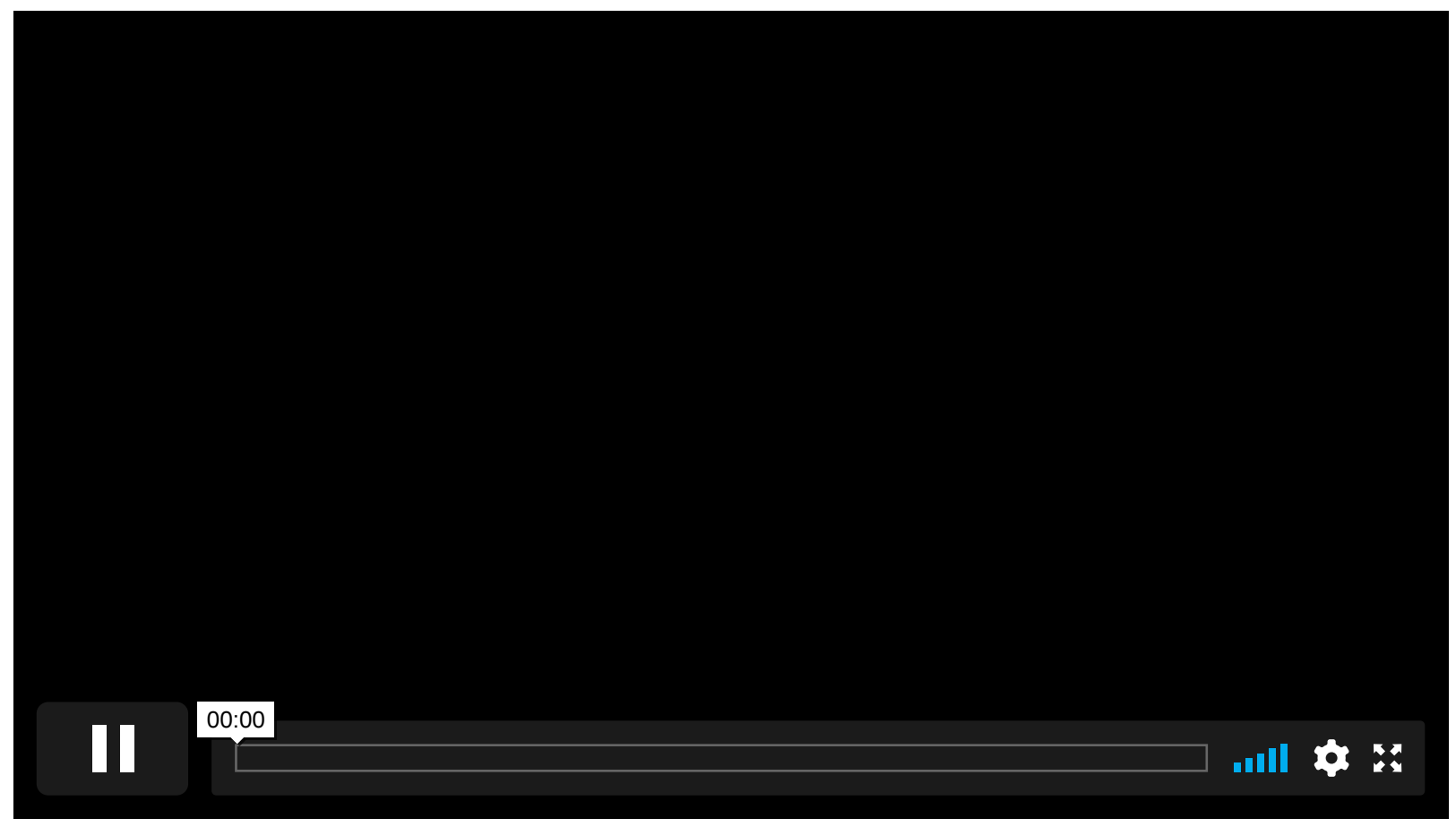

På oppfordring om å rapportere i fritekst om hva de så som styrker ved SIBSintervensjonen, blir flere aspekter beskrevet av helsesykepleierne. Noen av disse vil vi fremheve her:

Familieperspektivet til SIBS blir beskrevet som en styrke: SIBS gir mulighet til å forebygge vansker hos barn gjennom å styrke foreldre som samtalepartnere. Et annet aspekt som blir beskrevet, er SIBS' struktur og målrettede oppbygning med klart definerte metoder. Et tredje og kanskje mer overordnet aspekt som blir beskrevet som en styrke ved SIBS, er at søsken får møtes og gi hverandre støtte som likesinnede. 
Tross de positive evalueringene er det likevel skepsis å spore i helsesykepleiergruppen til muligheten for å gjennomføre SIBS i deres kommune (gjennomsnittsskår 4,7 på en skala fra 1 til 10). Selv om SIBS kan ledes av kun to gruppeledere, mener 79 prosent at tilgang på personalressurser vil utfordre gjennomføringen.

Det samme gjelder tilgang på deltakere. Til tross for at SIBS krever kun tre deltakende barn per gruppe, mener 64 prosent av helsesykepleierne at det vil være utfordrende å få samlet nok barn til gruppene innad i kommunen. Økonomi og kompetanse i å lede grupper blir også nevnt som en hindring av rundt en tredjedel av deltakerne, mens et fătall nevner tilgang på lokaler som en utfordring.

\section{Tverrfaglig samarbeid er en mangelvare}

Kan utfordringene overkommes gjennom $\varnothing \mathrm{kt}$ samarbeid? Helsesykepleiere har i tidligere studier fremhevet samarbeid som en viktig faktor i arbeidet med å forebygge psykiske helseplager (10).

Basert på vår kartlegging ser det ut til at samarbeid om tjenester til pårørende søsken er en mangelvare. Kun 2 av 92 deltakere rapporterer om samarbeid mellom tjenester innad i kommunen, og kun 10 om samarbeid med nabokommuner.

\section{«Flere forteller om samarbeid med interesseorganisasjoner enn om samarbeid med statlige eller kommunale instanser.»}

Hele 73 prosent av helsesykepleierne i denne studien oppgir at samarbeid med spesialisthelsetjenesten om ivaretakelse av søsken er fraværende eller svært begrenset. Det er flere som forteller om samarbeid med interesseorganisasjoner enn om samarbeid med statlige eller kommunale instanser om et tilbud.

Fafos rapport Trøbbel i grenseflatene (11) påpeker at manglende samarbeid mellom tjenester fører til at barn ikke får den oppfølgingen de har behov for. Barn som har en funksjonsnedsettelse, møter ofte helsepersonell både i spesialisthelsetjenesten (for eksempel i HABU (habiliteringstjenesten for barn og unge) eller BUP (barneog ungdomspsykiatrisk poliklinikk)) og i kommunen (for eksempel på helsestasjon eller i PPT), og alle disse fagpersonene har et selvstendig ansvar for å bidra til at søskens rettigheter til støtte følges opp. 


\section{Kommunene må ha barneansvarlige}

Men som ordtaket om for mange kokker tilsier, kan kanskje antallet involverte personer faktisk føre til mangel på tiltak. For hvem føler ansvaret? Og hvem har det overordnede ansvaret?

Da støtte til pårørende søsken ble lovpålagt i 2018, ble loven raskt fulgt opp med et krav om barneansvarlige på alle helseforetak (12). Det samme har ikke skjedd i kommunene.

Vi har gjort søk på nettet og lett etter barneansvarlige i kommunene.

Søkeresultatene viste at dette er en rolle som ofte tildeles en ansatt i en avgrenset kommunal tjeneste, da ofte psykisk helse og rus, for å ivareta barn som pårørende innad i denne tjenesten.

Mangel på barneansvarlige kan også leses ut av våre resultater. Barneansvarlig blir kun nevnt to ganger som en potensiell samarbeidspartner i arbeidet for å ivareta søsken. Langt flere oppgir derimot kreftkoordinatorer. Dette er kommunale stillinger finansiert av Kreftforeningen som kun dekker en svært liten undergruppe av søsken, nemlig søsken til barn med kreft.

I Norge lever det rundt 334000 barn med en funksjonsnedsettelse eller kronisk sykdom (13). Mange av barna har søsken. Noen $b \varnothing r$ ha det overordnede ansvaret for å ivareta disse søsknene i kommunene der de bor. På bakgrunn både av studien vår og vår kliniske erfaring fra arbeidet med pårørende søsken mener vi at en helsesykepleier kan være rett fagperson i denne rollen.

\section{Kurs i SIBS}

Frambu kompetansesenter for sjeldne diagnoser og Psykologisk institutt ved Universitetet i Oslo har i mange år forsket på og utviklet tiltak for søsken som pårørende. Frambu kan tilby kommunale tjenester et kompetanseløft.

Kurs i SIBS gjennomføres kostnadsfritt hvert halvår. Flere kommuner har sendt representanter fra ulike tjenester og med ulike fagprofesjoner på kurs for å trenes som et team som kan gjennomføre grupper i sin hjemkommune. Til sammen har nå 114 gruppeledere, blant dem flere helsesykepleiere, blitt kurset.

Bli med på å teste ut SIBS i din kommune! Meld din interesse ved å sende en epost til tva@frambu.no. 


\section{Referanser}

1. Helsedirektoratet. Helsepersonelloven med kommentarer. Oslo: Helsedirektoratet. Tilgjengelig fra: https://www.helsedirektoratet.no/rundskriv/helsepersonelloven-med-kommentarer (nedlastet 22.03.2021).

2. Haukeland YB, Fjermestad KW, Mossige S, Vatne TM. Emotional experiences among siblings of children with rare disorders. J Pediatr Psychol. 2015;40 (7):712-2O. DOI: 10.1093/jpepsy/jsvo22

3. Moen A. Dialogen med helsesykepleier gir unge mulighet til å påvirke egen helse. Sykepleien. 2019. DOI: 10.4220/Sykepleiens.2019.77232

4. Craig F, Operto FF, De Giacomo A, Margari L, Frolli A, Conson M, et al. Parenting stress among parents of children with neurodevelopmental disorders. Psychiatry Res. 2016;242:121-9. DOI: 10.1016/j.psychres.2016.05.016

5. Forandringsfabrikken Kunnskapssenter. Snakke snilt [internett]. Oslo: Forandringsfabrikken Kunnskapssenter; 2020 [sitert 18.03.2021]. Tilgjengelig fra: https://forandringsfabrikken.no/snakke-snilt

6. Otterstad HK. Får til mer effektiv kommunehelsetjeneste. Sykepleien. 2016;106(7):53-4. DOI: $10.4220 /$ Sykepleiens.2016.58048

7. Smith MM, Pereira SP, Chan L, Rose C, Shafran R. Impact of well-being interventions for siblings of children and young people with a chronic physical or mental health condition: a systematic review and meta-analysis. Clin Child Fam Psychol Rev. 2018;21(2):246-65. DOI: 10.1007/s10567-018-0253-X

8. Vatne TM, Haukeland YB, Mossige S, Fjermestad KW. The development of a joint parent-child intervention for siblings of children with chronic disorders. Fokus på familien. 2019;47(1):20-35. DOI: 10.18261/issn.0807-7487-2019-01-03

9. Haukeland YB, Czajkowski NO, Fjermestad KW, Mossige S, Silverman WK, Vatne TM. Evaluation of "SIBS", an intervention for siblings and parents of children with chronic disorders. J Child Fam Stud. 2020;29(8):2201-17.

DOI: $10.1007 / \mathrm{s} 10826-020-01737-\mathrm{x}$

10. Sand TI, Kvarme LG. Slik kan helsesøstre oppdage og forebygge psykiske plager hos ungdom. Sykepleien. 2018. DOI: 10.4220/Sykepleiens.2018.70421

11. Hansen I-LS, Jensen RS, Fløtten T. Trøbbel i grenseflatene. Oslo: Fafo; 2020. Fafo-rapport 2020:02. 
12. Helsedirektoratet. Pårørendeveileder. Helseforetak skal ha barneansvarlig personell [internett]. Oslo: Helsedirektoratet; [oppdatert 18.01.2018; sitert 18.03.2021]. Tilgjengelig fra:

https://www.helsedirektoratet.no/veiledere/parorendeveileder/helseforetak-ogkommuners-plikter-overfor-parorende/plikt-til-parorendeinvolvering-ogstotte/helseforetak-skal-ha-barneansvarlig-personell

13. Statistisk sentralbyrå. Sykelighet blant barn. Sykdom, skade eller funksjonshemming, etter kjønn og alder (prosent) [internett]. Oslo: Statistisk sentralbyrå; [oppdatert 25.06.2020; hentet 18.03.2021]. Tilgjengelig fra: https://www.ssb.no/statbank/table/06635/ 